\title{
Terence Ranger
}

Emeritus Professor, St Anthony's College,

Oxford and former Rhodes Professor of Race

Relations in the University of Oxford

Keywords: $\quad$ patriotic journalism, mass media, journalism history, political journalism, nationalism, Zimbabwe

\begin{abstract}
The article sees the rise of 'patriotic journalism' in recent Zimbabwe as representing something qualitatively different from any other forms of patriotism or journalism. The 'patriotic journalism' practiced by Jonathan Moyo's ministry from 2000-5, was narrowly defined and destructive. At a time when Socialism had been abandoned, education and welfare undermined, patriotic journalism emerged as the Zimbabwean government's last resort. The article unequivocally states that Zimbabweans ought not to be asked to tolerate destructive journalism in their country today because the Rhodesians used to do much the same or because the Western press is prejudiced. Zimbabweans must aspire for a better and more responsible journalism.
\end{abstract}

\section{Introduction}

I feel something of a fraud in opening this impressive day, stuffed full of journalists and specialists in media studies. I am neither. But perhaps it is a good idea, after all, to begin with a READER and that I can certainly claim to be. Indeed, now that I am no longer living in Zimbabwe, I read the newspapers published there with considerably more intensity than I did when I was recently a Visiting Professor at the University of Zimbabwe. Weeks could go by then without my seeing The Sunday Mail, and suffering no sense of loss as a result. Today, though, I rush with trembling fingers every Sunday morning to bring up the latest pronouncements of Mahoso. I strive, though with great internet difficulty, to keep abreast of Mzala Joe in the The Sunday News. And recently, of course, with the fascinating process of Jonathan Moyo's reluctant disengagement from the newspapers he has so long dominated, I have read The Herald and the The Chronicle in the way that Kremlinologists used to read Pravda and Izvestia.

Westminster Papers in Communication and Culture (C) 2005 (University of Westminster, London), Special Issue, November 2005: 8-17. ISSN 1744-6708 (Print); 1744-6716 (Online) 
Some of my academic colleagues, indeed, have accused me of taking newspapers too seriously. My friend, the great historian Ngwabi Bhebe, in a reply to my article on 'Patriotic History' has suggested that academic historians don't really need to worry themselves with what appears in the press; the radical historian David Moore has recently objected that commentators have attributed much too great importance to Jonathan Moyo, as though Zimbabweans might be fooled by his blatant propaganda. We certainly need the study of reception of propaganda which Miles Tendi intends to make for his Oxford doctorate. Maybe a reporter for Sokwanele was right to insist on February 192005 that:

those of us who were not permanently intellectually disabled by the constant drone of the electronic media or the failure of our schools to teach any analytical or creative thinking, easily recognised what came from Jonathan or one of his many aliases as blatant falsehood. We learnt to read between the lines, to look for the reality beyond the torrents and played games deducing what was really happening. We became pretty good at finding out the truth behind the lies.

Meanwhile, I can draw upon my past as a newspaper reader to help put things in perspective. The Sunday Mail today has much the same effect on me that The Sunday Mail used to have on me forty five years ago when I was first teaching at the University of Zimbabwe. In those days many uncertainties and irresolutions accumulated during each week. I was struggling to integrate the university residences, to desegregate hotels and cinemas and to work within the nationalist party. Many of my senior academic colleagues told me I was being rash and extreme; the white Rhodesian press attacked me as an agitator. But all doubts were banished in a rush of righteous anger every Sunday when I read the racist and reactionary columns of The Sunday Mail. I know that it has always represented the ideological extreme and that we are not now dealing with the tragic decline of a great tradition of independent journalism.

In a similar way, the words The Daily News mean for me, first and foremost, the paper which Nathan Shamuyarira used to edit forty five years ago - a better paper in some ways, than any of its successors because fuller of news rather than comment. Indeed, its comment was often critical of nationalist leaders while its news made them household words for Africans. That The Daily News was also banned.

Even as a historian, I have been a great reader of newspapers. I have read through every copy of the The Bantu Mirror three separate times - for my research on the Matopos, on the Samkange family, and now on the social history of Bulawayo. I have read through the whole run of Charlton Ngcebetsha's The Home News, from its beginnings in Mkokoba, to its ending in Gonakudzingwa. I have read Parade, for the 1950s and 1960s, and the The Chronicle for the 1920s, 1940s and 1960s. I have 
read the nationalist journals, Chaрири and The Democratic Voice; I have read the ZAPU and ZANU liberation war journals. In short, I have read more Zimbabwean newspapers than any man should sensibly have done, and I know only too well how race and class interests shape them and how one maverick from Ngcebetsha to Moyo - can use the press to settle personal scores.

I ought to be armoured, then, against imagining that only recently have Zimbabwean newspapers become prejudiced and propagandistic. And I know very well, of course, that too many newspapers in Britain and the United States serve the national and imperial interests of those countries. Nevertheless, and despite all this, I do think that the rise of 'patriotic journalism' represents something qualitatively different. And I do not think that Zimbabweans ought to be asked to tolerate destructive journalism in their country today because the Rhodesians used to do much the same or because the Western press is prejudiced. Zimbabweans deserve better than this.

Let me first examine that word 'patriotic', which I employed in my article on patriotic history (Ranger, 2004). It is a treacherous word, of course. Anyone criticising 'patriotic' history or 'patriotic' journalism can be accused of wanting the opposite. As one Zimbabwean intellectual is reported to have said about my article, 'What does he want then? Unpatriotic history?' Of course, I don't want unpatriotic history or unpatriotic journalism. The term 'patriotic history' I took up from Zimbabwe government announcements and state press commentary. 'Patriotic history' is what is taught in militia camps and what is being offered under the guise of 'National and Strategic Studies in Teacher Training Colleges and Polytechnics. 'Patriotic journalism' is what had been practised during the regime of Jonathan Moyo. This kind of history and this kind of journalism is narrow and divisive - a substitute for ideology and analysis.

When I think about it, I recall Dr Samuel Johnson's famous definition of 'patriotism' in his dictionary - 'the last refuge of a scoundrel'. Johnson didn't like disloyalty or treachery either. What he abominated was an exclusive appeal to patriotism which defined everyone else as a traitor. I was reminded of Johnson this week when I was transcribing letters which I had written to my close friend and political ally John Reed in the 1960s. On 13 August 1964, I quoted to John from a letter I had received from Stanlake Samkange, himself a distinguished journalist. Stanlake had become Chairman of ZANU in Highfields and had been attacked and stoned by ZAPU youth:

I appear to have come to the conclusion (he wrote me) that one of the most important principles my father taught me - the love of one's fellowmen and sacrifice and service towards other people is not worth it and is plain rubbish. I mean every word I say, Terry, and I believe that Number One is the most 
important thing in life and to hell with everybody ... African women are having their hair cut by youth in the street and African is murdering African and being proud of it. Is this sense? Is this patriotism?

In another letter to John Reed, on 27 March 1965, I quote from some ZANU attacks on ZAPU out of a ZANU broadsheet. It is an early, though I don't suppose the earliest, example of patriotic journalism, demonising ZAPU and exalting ZANU's love of country. ZAPU, it says, has been bought by the supplies which white liberals ferry to its leaders in Gonakudzingwa restriction area. It is 'recanting, revisionist, recoiling and infested with white settlers - a multi-racial mixed grill'. By contrast ZANU members stand by their oath:

I will take an eye for an eye and a tooth for a tooth. I swear to avenge myself bitterly, unceasingly and mercilessly on the enemy ... I swear by my MOTHERLAND -ZIMBAWE- or DEATH.

I found this fascinatingly reminiscent of recent pronouncements, for instance the ZANU PF booklet Traitors Do Much Damage to National Goals, reported in The Independent on 18 February 2005. Of course, despite the sharp distinction made both in 1965 and 2005 between 'sell-outs' and 'traitors' the characters on either side of that same line have changed greatly in forty years. In 1965, Joshua Nkomo was 'recanting, revisionist and recoiling'; in 2005 he has a secure place in the patriotic pantheon as 'Father Zimbabwe'. In 1965 Ndabaningi Sithole was hailed as the leader of all true patriots; in the 2005 list of traitors he is included as one of those who 'betrayed the liberation war'. As my letters to John Reed document in detail between 1963 and 1965, Robert Mugabe was among those who campaigned in London for a British intervention in Rhodesia. Today the ZANU PF booklet says that 'the epicentre of hell is in Britain and the Queen or King in power at that moment is the devil himself or herself.

Patriotic journalism, then, is a revival -or a set of variations upon - the rhetoric of nationalist division in the 1960s. When I spoke earlier about its 'rise', I ought to have talked about its 'return'. Just as in 1965, hate journalism is the product of challenge and division in Zimbabwean African politics. But I stick to my contention that it is now qualitatively different. The ZANU broadsheet of 1965 was marginal, reaching very few readers. Patriotic journalism now is only part of a great orchestration of propaganda, accompanied by state television and radio.

It is instructive to contrast Zimbabwe in its 25th year to Zimbabwe in its first year of independence. In 1980, one might say, the new regime neither needed nor could enforce patriotic history. It did not yet completely control the press. But more importantly the argument about which nationalist party was the stronger had been settled for the time being by the 1980 election result; Britain was a friend; the 
policy of reconciliation prevented reference back to the atrocities of the war. (When Granada television wanted to make a film in Zimbabwe of one of Nadine Gordimer's short-stories set in war-torn Rhodesia Nathan Shamuyarira, as Minister of Information, prohibited it from doing so in the name of reconciliation - the film had to be shot in Uganda, among incongruous banana groves). Above all, the new regime had positive programmes and ideologies. It did not need to fall back on patriotism as a 'last refuge'. It could offer socialism, education, welfare.

By 2000, it was in a very different position. Socialism had been abandoned, education and welfare undermined. It was time once again for the last resort of patriotic journalism. Indeed, Jonathan Moyo has maintained this week that it was he who saved ZANU PF in 2000 when it seemed bankrupt of ideology and policy, and when everyone else was despairing. Ngwabe Bhebe and David Moore will take this claim with a large pinch of salt and perhaps we should all do so. Moyo himself, though, has had no doubts about the scale of his achievements.

In The Sunday Mail for 10 October 2004, for instance, a modestly named but thinly disguised 'Features Reporter' wrote a long hymn of praise to the Department of Information and Publicity, awarding it 'a straight A for [its] policy over the past four years ... The Department has not only done its job for Zimbabwe, but for Africa and the world. In effect they are now a Department of Information and Publicity in the Office of the President, Cabinet, Continent and the World!'

The report chose to focus particularly on Jonathan Moyo's use of music - his jingles incessantly repeated on TV and radio; his concerts and CDs. The revolutionary message had been transmitted 'through the language of music' and such music 'will always be recognised and loved by true patriots'. Great artists 'noticed nobility behind the efforts of the Department' and gave it a voice. But if the message is claimed as global its expression has adopted the rhetoric of heroes and 'sell-outs': in the 2000s the voice comes as it did in the 1960s (but not in the 1980s) from that patriotic place of last resort.

Anyone who does not appreciate Moyo's music or its message is by definition a traitor. The regime's musicians have been 'hounded by opposition-funded antirevolutionary propaganda mouthpieces as copycats and one-hit wonders'. Their music shows that Zimbabwe is really a 'united country despite what pretenders in the political jungle meant to say, as they frequented the graves of the past to refresh wounds, masochistically wanting to whip people into a frenzy and a counter-productive revolution'. The record made there proves that the Victoria Falls is really located entirely in Zimbabwe: 
much as the western media tried to dissuade tourists from visiting one of the greatest natural wonders of the world, there was no taking the Falls away. They are a Zimbabwean land-mark and nothing can change that ... they are in Zimbabwe and not Zambia as the British media in particular tried to force upon the people.

And if Moyo's music had to be defended with such extreme patriotic rhetoric so too did his newspapers against any possible challenge. On 9 January 2005, for instance, The Sunday Mail carried a piece by Lowani Ndlovu entitled 'new paper seeks to divide nation'. This was an attack on the Bulawayo-based The Weekly Times couched in the language of hate-speak:

Every now and then, especially towards any crucial election, our intellectually challenged 'brothers' in the Rhodie shadow, generally known as the MDC, have a penchant for coming up with the inane, right down to the treacherous.

The new weekly, Ndlovu writes, leads:

\begin{abstract}
'with a story based on the mis-observations of one of Africa's chief clerics in the axis of clothed evil, Pius Ncube, who along with the little Archbishop Desmond Tutu, takes every platform to demonise the empowerment of the black majority, in the sacred name of the church ... giving the hollow-skulled Archbishop Ncube a pedestal to rant and rant, talking Fifth Brigade this, genocide that, all in a mischievous plot to please their white masters. Begging for the pork-skinned to return and harness them to a yoke.'
\end{abstract}

Lowani goes on in high 1965 mode: 'pandering to the whims of the gay gangsters they are in fact saying 'come and defile us and our Africa, come take our land and rape our women'. Can Lowani or anyone else really believe that this is what Archbishop Pius is saying? As I read this sort of stuff, I find myself repeating Stanlake Samkange's questions: 'Is this sense? Is this patriotism?'

Yet hate journalism has flourished. If the world is divided into patriots and sellouts nothing is too vile to be said about those allocated to the side of Judas, the biblical figure most frequently invoked in the state press. I quoted some ripe examples in my lecture last year in Uppsala, report after report talking of the 'enemy within' and of the parallels that could be drawn between Jesus and Mugabe, since both had been betrayed by their own disciples. Here I quote a few more recent examples to make a point that does not need to be belaboured to this audience.

Here, for example, is the notorious Nathaniel Manheru expressing himself with his customary and open bile against the NGOs: 
I do not care what reprisals I draw from this tribe of depressed bipeds working for the so-called NGO industry ... Simply put these bipeds are a dishonest lot, right down to the man, yes, right down to the woman. They crave, feed and fatten on human tragedies ... much the same way maggots grow white-fat on decaying carcasses; much the same way green flies obey the pull of human effluvia, all in the hope of a prized find of a mount of decaying dung and muck ... I do not like them at all and make no effort to hide it. Like real vermin, they do not welcome good news.

Zimbabwean NGO workers are 'given to riotous binges in the leafy suburbs of Harare, where music, drink and sex, spiced by irreverent gossip are swapped freely in this norm-less world'. Above all they are unpatriotic. They cannot allow Zimbabwe to succeed, 'regardless of good harvests and economic recovery. It must remain torn by gratuitous political violence ... Zimbabwe has to remain a crisis lest Kagoro's Crisis Coalition ceases to have money and meaning. Their 'mission for governance pits them against the poor of this world, against the governors of this land, on behalf of bitter Blair, bitter settler white farmers. Yes, on behalf of bitter Tsvangarai, himself a creation of the first two.'

In this journalism, Zimbabweans are divided into patriots and traitors; the rest of the world is divided into supporters and imperialists. And there are fewer and fewer trustworthy supporters left. The Swedes and the Danes used to be among them but now they have revealed their true identity as 'neo-liberals'. And this time Manheru throws in for good measure the almost incorrigibly amiable Czech Ambassador, supporter of Zimbabwean art and literature, who had dared to make some criticism:

His is no donor country; his is no imperial country. In fact the then Czechoslovakia was a friend of liberation movements ... [but] maybe its proud association with national freedom struggles went with the Slovak republic, leaving none for its Czech excision. If this is what he wants to convince Southern Africa, the same way the Swedes and Danes have done, so be it. We shall oblige and shall be happy to put him in league with the worst representation of imperial Britain.

One last example, again by Manheru, writing in The Herald of 18 September 2004. This time he was attacking white fellow-travellers of the Zimbabwean revolution who 'drifted into the country at Independence to feed on the fat of the happy outcome of our sacrifices as black Zimbabweans'. There had been no true white revolutionaries:

I can only recall one white man who actually joined the military ranks of the Patriotic Front, on the side of ZIPRA. Otherwise Rhodesia produced no Joe Slovos, no Ruth Firsts, only Ian Smiths of varying hues ... From the 
point of view of our collective quest for liberation, Rhodesia bore no good white men, and that makes the whole lot complicit in colonial atrocities, the whole lot guilty, yes, fitting candidates for an African Nuremberg.

I realise that I was lucky in August last year to be attacked only by an amateur hate journalist and only in the Daily Mirror, though he called me 'an academic tourist' and coined the vivid epithet for me of 'an ululating bull-dog'!

The point of all this is certainly not that NGOs or the EU or Rhodesian whites or expatriate historians should be exempt from criticism. I am sure that they will all come under rigorous scrutiny during this workshop. Indeed, I have many criticisms and self-criticisms to make myself. The point though is that this sort of 'patriotic' hate journalism, with its absolute division of the world into good and evil, makes any rigorous discussion impossible. It lumps incompatibles together the national hero Guy Clutton-Brock and the provincial hero John Conradie and the unsung hero Peter Mackay along with Ian Smith and the Nuremberg defendants; NGOs that have fed starving children and healed the traumas of wartime violence along with American right-wing financiers of regime change. It prevents any self-reflection on the part of the regime because criticism of any kind can at once be categorised as treasonable and imperialist. It enables its exponents to invent desired realities, like 'good harvests and economic recovery' or a Victoria Falls entirely surrounded by Zimbabwe.

And yet, absolute though it is, patriotic journalism is also astonishingly flexible. People pop in and out of the pantheon of heroes and shame-lists of traitors. And I have found it fascinating to watch how nationalism and the freedom struggle, those key ingredients of patriotic credentials, are constantly redefined and reassembled. The historic churches were once allocated a positive role in the liberation struggle - there were once even admired bishops. Now bishops are 'evil little men' and we are told that Tutu was a worshipper of apartheid all along. Once the Zionist and Apostolic churches, with their resistance to statism and development, were seen as dangerous mavericks. Today Mugabe dances with them at Heroes Acre.

Once Trade Unions were seen as pioneers of struggle and as key allies of nationalist parties. It was hard to tell whether Joshua Nkomo or J.Z. Moyo were unionists or party leaders. Today the patriotic press tells us that trade unionism has never been a reliable ally. The Congress of South African Trade Union (COSATU), The Sunday Mail tells us on 6 February 2005, is 'now clearly at the beck and call of white capital'; trade unions in general with their international connections and 'neo-liberal' rhetoric of rights have been suborned against nationalist states. The Sunday Mail on 6 February went on allege that because COSATU 'had demonstrated its capacity to have street power' the ICFTU had 
been 'keen to commandeer that street power against the liberation movements in the Sadc region'. There was an emerging coalition of trade unions, Non Governmental Organisations (NGOs) and the South African Communist party against the national movement. COSATU said The Herald on 2 February, was indicating left and turning right. "Although the trade union movement was strong enough to mobilise support against the apartheid regime, it has either been slow or has failed dismally to grasp protocols, rules and intricacies involved in governing a country'. Now it 'seeks total political power at the expense of its ally, the ANC'.

All this is described as part of a pattern of destabilisation - 'the transformation of labour movements into puppet political parties is not a new thing in southern Africa', wrote Munyaradzi Huni in The Sunday Mail of 19 December 2004. 'In Zambia Frederick Chiluba's Movement for Multi Party Democracy started as a labour movement but was later transformed into a political party that got into power in 1991. In Zimbabwe, the same trick was tried.' Trade Unions, wrote Caesar Zvayi in The Herald of November 10 2004, had 'always shifted positions with sickening prurience' and 'in typical post-modernist fashion'.

Yet divested of the churches and the trade union movement and civil society and urban residents, the post-liberation state, with its own shifting positions, appears vulnerable. In Zimbabwe today the liberation struggle has been defined as solely about land and solely in alliance with 'the peasantry'. I have written about Peasant Consciousness and Guerrilla War myself (Ranger, 1985). But the ambivalences and ambiguities of the relationship of the peasantry to the state are concealed and mystified by patriotic journalism.

To return to my beginning, I am aware that I have allowed the terrible seductions of Jonathan Moyo's prose, under all its aliases, to lure me into quoting him as the epitome of patriotic journalism. Now that Moyo himself is moving from the pantheon of heroes to the list of traitors and sell-outs it may be that an era is ending. One of my MA students, now teaching History in a Zimbabwean University, has emailed me to rejoice that the hate-filled young turks have been put in their place by 'sensible old nationalists'. That should mean the end of the project of patriotic history, he thinks. I am not so sure. Moyo was not the whole either of patriotic history or patriotic journalism. Their animating ideas, after all, spring from Mugabe himself. We shall have to see how the state media develop postMoyo. A great purge of Moyo's appointees is already under way in the press and in ZTV and radio. We must watch closely to see whether the new men and women continue with patriotic journalism, merely adding Moyo and his clients to the hatelist or whether they will develop more inclusive and less divisive ways of serving the interests of the nation. 
Ranger, The rise of patriotic journalism...

\section{References}

Ranger, T. (2004) 'Nationalist Historiography, Patriotic History and the History of the Nation: the Struggle over the Past in Zimbabwe', Journal of Southern African Studies 30(2): 215-234.

Ranger, T. (1985) Peasant Consciousness and Guerrilla War, London: James Currey. 